[Report]

\title{
Frequent Oxygen Desaturation During Sleep on the Day of Bronchoscopy Evaluated by Continuous Pulse Oximeter Monitoring
}

\author{
Yasuo ChoJIN ${ }^{1,2 *}$, Hiroshi Ishimoto ${ }^{1,3}$, Shingo Noguchi ${ }^{1}$, Toshinori Kawanami ${ }^{1}$, Tatsuji Kato $^{2}$, Hiroshi MukaE ${ }^{1,3}$ \\ and Kazuhiro YATERA ${ }^{1}$ \\ ${ }^{1}$ Department of Respiratory Medicine, School of Medicine, University of Occupational and Environmental Health, \\ Japan. Yahatanishi-ku, Kitakyushu 807-8555, Japan \\ ${ }^{2}$ Department of Respiratory Medicine, Tobata Kyoritsu Hospital. Tobata-ku, Kitakyushu 804-0093, Japan \\ ${ }^{3}$ Department of Respiratory Medicine, Second Department of Internal Medicine, Nagasaki University School of Medi- \\ cine, Nagasaki 852-8102, Japan
}

\begin{abstract}
To perform a bronchoscopy safely, it is very important to make a risk assessment before and after the procedure. There have been no reports of hypoxemia during sleep on the day after a bronchoscopic examination; therefore, we evaluated the oxygen saturation status during sleep on the days before and after bronchoscopy. Thirty patients that underwent bronchoscopy were studied. Continuous pulse oximetry monitoring was performed on the day before bronchoscopy and the day when the bronchoscopy was performed. The average oxygen saturation levels and the oxygen desaturation index (ODI) were evaluated. There was a significant increase $(P<0.05)$ in the ODI-3\% during sleep on the day of the bronchoscopy compared to the day before the bronchoscopy. Clinicians should pay careful attention to hypoxia not only during bronchoscopy, but also during sleep on the night following the procedure.
\end{abstract}

Keywords : continuous pulse oximeter monitoring, sleep, bronchoscopy, oxygen desaturation.

(Received March 22, 2017, accepted July 26, 2017)

\section{Introduction}

Oxygen desaturation frequently occurs during bronchoscopic examinations, and oxygen saturation is typically monitored during bronchoscopy. It is possible that the procedure of bronchoscopy may cause prolonged hypoxia in some patients, but, to the best of our knowledge, there are no reports describing oxygen desaturation status during sleep at night on the day of bronchoscopy. We investigated this issue by retrospectively evaluating the oxygen saturation status at night on the days before and after bronchoscopy in 30 patients.

\section{Patients and Methods}

Thirty out of 631 patients who had undergone bronchoscopy at our university hospital between December 2012 and March 2014 were enrolled in our study (Fig. 1). The oxygen saturation status during sleep on the night before and on the day of bronchoscopy were evaluated. Oxyhemoglobin saturation measured

*Corresponding Author: Yasuo CHOJIN, Department of Respiratory Medicine, School of Medicine, University of Occupational and Environmental Health, Japan. Yahatanishi-ku, Kitakyushu 807-8555, Japan, Tel: +81-93-691-7453, Fax: +81-93-602-9373, E-mail: choppy001042@med.uoeh-u.ac.jp 


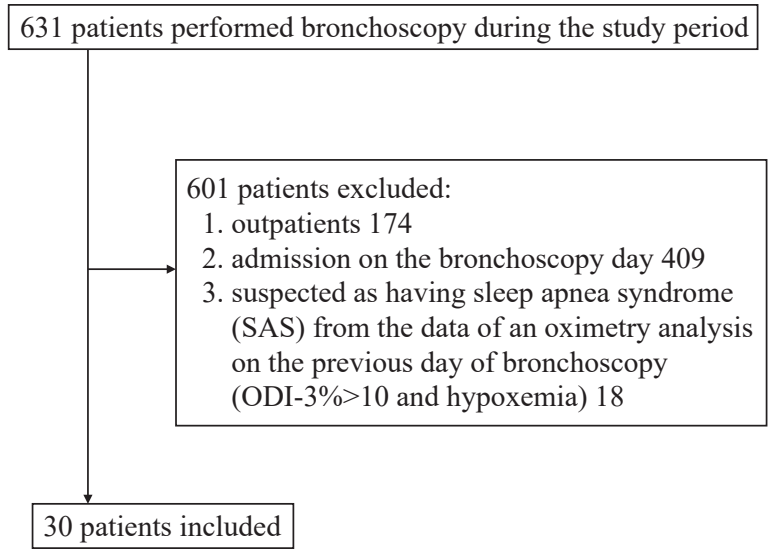

Fig. 1. Flow chart of patients' seletion. ODI: oxygen desaturation index.

by pulse oximeter $\left(\mathrm{SpO}_{2}\right)$ was monitored by Pulsox-2 (Konica Minolta, Inc., Japan) and the oxygen desaturation index (ODI) was analyzed by DS-Me (Konica Minolta, Inc., Japan). The ODI-3\% was defined as the total number of at least $3 \%$ decreases of $\mathrm{SpO}_{2}$ per hour. Local inhalation anesthesia using a $4 \%$ concentration of lidocaine (200 mg) was used just before the bronchoscopic examination. Intravenous sedative medication (midazolam $3 \mathrm{mg}$ ) was also used just before the bronchoscopy. The bronchoscopic procedures were performed between 9 a.m. and 3 p.m. We retrospectively reviewed the $\mathrm{SpO}_{2}$ and the ODI-3\%.

The study complied with the Declaration of Helsinki, and was approved by the Human and Animal Ethics Review Committee of the University of Occupational and Environmental Health, Japan (No. H28-235). The mean age of the 30 patients was $64.4 \pm 16.2$ (mean \pm standard deviation; SD) years and males/females were 16/14. The bronchoscopic procedures included various combinations of bronchoalveolar lavage (BAL), bronchial washing, transbronchial lung biopsies, bronchial brushing, and endobronchial ultrasound-guided transbronchial needle aspiration; and BAL was primarily performed in 12 patients. 29 patients were put on oxygen, and no patients had noninvasive ventilation. Bronchoscopy did not have to be discontinued in any patients, and there were no complications (Table 1).
Table 1. Characteristics of 30 patients that underwent bronchoscopy

\begin{tabular}{ll}
\hline Age (years): mean \pm SD & $64.4 \pm 16.2$ \\
Female sex: $\mathrm{n}(\%)$ & $14(46.7)$ \\
BMI: mean \pm SD & $20.9 \pm 4.8$ \\
Pulmonary disease: $\mathrm{n}(\%)$ & \\
Interstitial pneumonia & $7(23.3)$ \\
Lung cancer & $6(20.0)$ \\
Sarcoidosis & $4(13.3)$ \\
Chronic lower respiratory tract infection & $4(13.3)$ \\
Pulmonary alveolar proteinosis & $2(6.7)$ \\
Hemoptysis & $2(6.7)$ \\
Nontuberculous mycobacteriosis & $1(3.3)$ \\
Chronic obstructive pulmonary disease & $1(3.3)$ \\
Pulmonary cyst & $1(3.3)$ \\
Laryngeal cancer & $1(3.3)$ \\
Comorbidity: $\mathrm{n}(\%)$ & \\
Hypertension & $7(23.3)$ \\
Diabetes mellitus & $3(10.0)$ \\
Pulmonary hypertension & $3(10.0)$ \\
Chronic cardiovascular disease & $6(20.0)$ \\
Sleeping medications: $\mathrm{n}(\%)$ & $4(13.3)$ \\
Anxiolytic medications: $\mathrm{n}(\%)$ & $2(6.7)$ \\
Period of AM performed bronchoscopy: $\mathrm{n}(\%)$ & $9(30.0)$ \\
Examination time (minutes): mean \pm SD & $24.8 \pm 14.6$ \\
BAL: $\mathrm{n}(\%)$ & $12(40.0)$ \\
Purpose of bronchoscopy (Diagnostic): $\mathrm{n}(\%)$ & $28(93.3)$ \\
\hline
\end{tabular}

SD: standard deviation, BMI: body mass index, AM: ante meridian, BAL: bronchoalveolar lavage

\section{Results}

A transient decrease of $\mathrm{SpO}_{2}$ occurred during the procedure of the bronchoscopic examination, but this desaturation recovered rapidly within three hours. No significant differences were noted in the average values of $\mathrm{SpO}_{2}$ and the pulse rate between sleep at night on the previous day and on the day of bronchoscopy $\left(\mathrm{SpO}_{2}\right.$ $95.9 \pm 1.3 \rightarrow 95.3 \pm 1.6$, pulse rate $66.7 \pm 11.0 \rightarrow 67.1$ \pm 9.5 ). In contrast to these findings, there was a significant increase in the ODI-3\% during sleep at night on the day of bronchoscopy compared with the day before bronchoscopy (Fig. 2). No significant differences were noted in the $\triangle \mathrm{ODI}-3 \%$ between those who underwent BAL (12 patients, $\Delta \mathrm{ODI}-3 \%=1.2 \pm 2.3$ ) and those who did not (18 patients, $\triangle \mathrm{ODI}-3 \%=2.8 \pm 2.7$ ). Based on the findings of the ODI, 22 patients were included in the increase of ODI group ( $\triangle \mathrm{ODI}-3 \%$ was more than 1 and $\Delta \mathrm{ODI}-3 \%$ was more than $20 \%$ of the ODI of the previous day) and 8 were included in the non-increase 
of ODI group. A univariate analysis showed no factor to be a siginificant risk factor for the increase of ODI (Table 2).

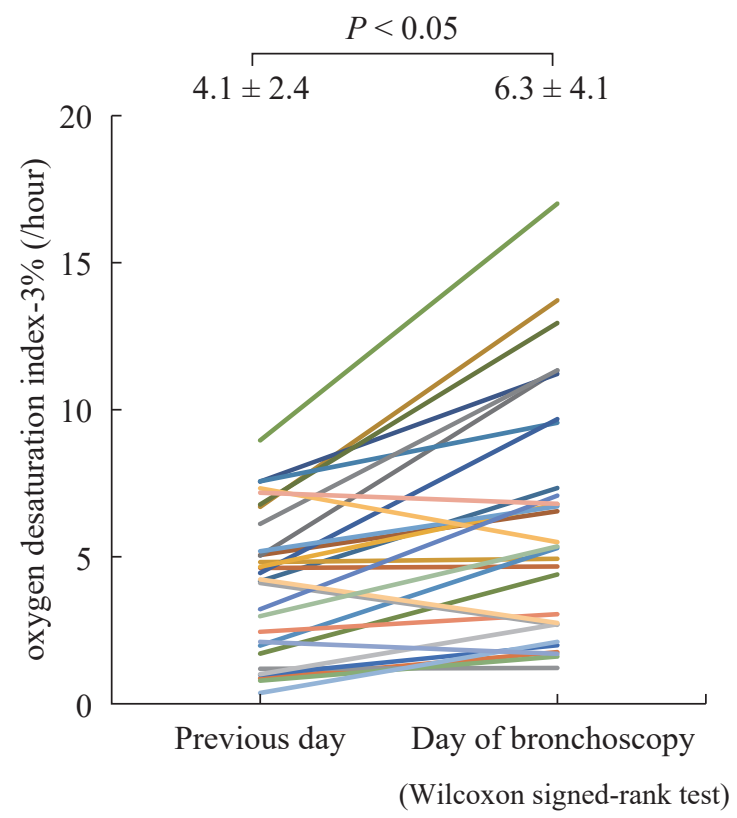

Fig. 2. Changes in the oxygen desaturation index (ODI)-3\% on the previous day and the day of bronchoscopy. An increase in the ODI- $3 \%$ during sleep on the day of bronchoscopy compared with the previous day was noted $(P<0.05)$. Colored lines mean 30 patients.

Table 2. A univariate analysis of the increase of ODI

\begin{tabular}{|c|c|c|c|}
\hline Factor & $\begin{array}{l}\text { the increase } \\
\text { of ODI } \\
\text { group } \\
(\mathrm{n}=22)\end{array}$ & $\begin{array}{l}\text { the non- } \\
\text { increase of } \\
\text { ODI group } \\
(\mathrm{n}=8)\end{array}$ & $P$ value \\
\hline Age (years): mean $\pm \mathrm{SD}$ & $64.5 \pm 17.1$ & $64.3 \pm 12.0$ & NS* \\
\hline Female sex: n (\%) & $10(45.5)$ & $4(50.0)$ & NS** \\
\hline BMI: mean \pm SD & $20.6 \pm 4.1$ & $21.6 \pm 6.2$ & NS* \\
\hline Hypertension & $5(22.7)$ & $2(25.0)$ & NS** \\
\hline Diabetes mellitus & $2(9.1)$ & $1(12.5)$ & NS** \\
\hline Pulmonary hypertension & $2(9.1)$ & $1(12.5)$ & NS** \\
\hline $\begin{array}{l}\text { Chronic cardiovascular } \\
\text { disease }\end{array}$ & $4(18.2)$ & $2(25.0)$ & $\mathrm{NS}^{* *}$ \\
\hline Sleeping medications: n (\%) & $2(9.1)$ & $2(25.0)$ & NS** \\
\hline Anxiolytic medications: n (\%) & $2(9.1)$ & $0(0.0)$ & NS** \\
\hline $\begin{array}{l}\text { Period of AM performed } \\
\text { bronchoscopy: } \mathrm{n}(\%)\end{array}$ & $6(27.3)$ & $3(37.5)$ & NS** \\
\hline $\begin{array}{l}\text { Examination time (minutes): } \\
\text { mean } \pm \text { SD }\end{array}$ & $24.9 \pm 14.4$ & $24.6 \pm 15.2$ & NS* \\
\hline BAL: n (\%) & $8(36.4)$ & $4(50.0)$ & NS** \\
\hline
\end{tabular}

ODI: oxygen desaturation index, SD: standard deviation, BMI: body mass index, AM: ante meridian, BAL: bronchoalveolar lavage, *: Mann-Whitney $U$ test, **: Chi-squared test, NS: not significant

\section{Discussion}

In this study, there was a significant oxygen desaturation during sleep in the night on the day of bronchoscopy compared to that on the day before the procedure, observed as an increase in ODI-3\%. A significant correlation between ODI-3\% and the polysomnographyapnea hypopnea index has been previously reported [1], but, to the best of our knowledge, there have been no previous reports on a change in ODI- $3 \%$ on the day of bronchoscopy.

There are several assumed mechanisms of desaturation during sleep at night on the day of bronchoscopy. First, it is assumed that the medications used just before bronchoscopy have an influence; for example, inhalation use of lidocaine and intravenous use of midazolam could be one of the reasons for the increase in the ODI-3\% during sleep on the day of bronchoscopy. However, inhalation use of lidocaine has a very short half-life activity within 10 minutes, and midazolam is also a short-acting benzodiazepine with an elimination half-life of approximately 2 hours [2], and at least 8 hours passed after the inhalation of lidocaine and intravenous injection of midazolam. Therefore, an increase in the ODI-3\% during sleep at night on the day of bronchoscopy may not be related to lidocaine and midazolam use. There were no control patients without midazolam use in this study, thus further investigations on the influence of midazolam use on an increase in ODI-3\% in patients receiving bronchoscopic examinations are necessary.

Second, bronchoscopic procedures, such as BAL, could also influence the oxygen saturation status at night. BAL induces hypoxia during the bronchoscopic procedure, but it has been previously reported that patients recovered from hypoxia within one hour after BAL [3]. In this study there were no differences in the $\triangle \mathrm{ODI}$ $3 \%$ at night on the day of bronchoscopy between patients in whom BAL was performed and those who did not undergo BAL; therefore, BAL was most likely not the main cause of hypoxia during sleep at night on the day of bronchoscopy. No factor was seen to cause the difference between the increase of ODI group and non-increase of ODI group in this study. Further largemulticenter study might be needed to perform in order to clarify this point. 
Sleep apnea syndrome-associated hypoxia can cause myocardial ischemia in patients with coronary heart disease [4]. Hypoxia may be corrected by supplemental oxygen during bronchoscopic procedures, but bronchoscopy-associated hypoxia during sleep at night on the day of bronchoscopy can possibly cause myocardial ischemia in patients with ischemic heart disease. Therefore, nocturnal hypoxia on the day of bronchoscopy should also be monitored and treated.

In conclusion, we retrospectively evaluated the oxygen saturation status during sleep at night only on the day of bronchoscopy, and an increase in the ODI-3\% frequently occurred at that time. It may be possible that prolonged bronchoscopy-associated hypoxia during sleep at night for several days after bronchoscopy and bronchoscopy-associated hypoxia could have negative effects on pre-existing pulmonary and cardiac diseases. We must pay careful attention to hypoxia not only during bronchoscopy, but also during sleep at night after bronchoscopy. Further investigations to evaluate bronchoscopy-associated hypoxia during sleep on the day of bronchoscopy are necessary to ver- ify the duration of bronchoscopy-associated hypoxia during sleep at night.

\section{Conflict of Interest}

The authors declare that they have no conflict of interest.

\section{Reference}

1. Ling IT, James AL \& Hillman DR (2012): Interrelationships between body mass, oxygen desaturation, and apnea-hypopnea indices in a sleep clinic population. Sleep 35: 89-96

2. Matot I \& Kramer MR (2000): Sedation in outpatient bronchoscopy. Respir Med 94: 1145-1153

3. Gibson PG, Breit SN \& Bryant DH (1990): Hypoxia during bronchoalveolar lavage. Aust N Z J Med 20: 39-43

4. Schäfer H, Koehler U, Ploch T \& Peter JH (1997): Sleeprelated myocardial ischemia and sleep structure in patients with obstructive sleep apnea and coronary heart disease. Chest 111: 387-393 
連続酸素飽和度モニタリングを用いた気管支鏡検査当日の睡眠時における酸素飽和度低下の検証

長神 康雄 ${ }^{1,2}$, 石本 裕士 ${ }^{1,3}$, 野口 真吾 ${ }^{1}$, 川波 敏則 ${ }^{1}$, 加藤 達治 ${ }^{2}$, 迎 寛 ${ }^{1,3}$, 矢寺 和博 ${ }^{1}$

1 産業医科大学 医学部 呼吸器内科学

2 戸畑共立病院 呼吸器内科

${ }^{3}$ 長崎大学 医学部 呼吸器内科学

要旨：気管支鏡検査前後のリスクアセスメントは, 気管支鏡検査を安全に実施するために重要である。しか し,気管支鏡検査当日の睡眠時の低酸素血症の有無を調べた報告はなく,我々は気管支鏡検査前日と当日の睡眠時の 酸素飽和度について検証した。 30 症例で連続パルスオキシメーターを用いて, 気管支鏡検査前日と当日の睡眠時の 酸素飽和度低下指数 $(\mathrm{ODI})$ を測定した。その結果, 気管支鏡検査前日に比べて気管支鏡検查当日の睡眠時の酸素飽 和度低下指数 $(\mathrm{ODI}-3 \%)$ は有意に上昇し $(P<0.05)$, 気管支鏡検査による低酸素をきたしていた。気管支鏡検査を実 施する際には気管支鏡検査中だけではなく,気管支鏡検査後の睡眠時の低酸素血症にも注意すべきである.

キーワード：連続酸素飽和度モニタリング, 睡眠, 気管支鏡検査, 酸素飽和度低下. 